FACTA UNIVERSITATIS

Series: Law and Politics Vol. 17, N 1, 2019, pp. 1-22

https://doi.org/10.22190/FULP1901001J

Original Scientific Paper

\title{
AN OVERVIEW OF THE INTERNATIONAL \\ SCIENTIFIC-PROFESSIONAL MEETING \\ AT THE APPELLATE COURT IN NIŠ WITHIN THE PROJECT \\ "STRENGTHENING THE PROBATION AND THE SYSTEM OF ALTERNATIVE SANCTIONS IN MONTENEGRO AND SERBIA" Niš, $4^{\text {th }}$ December 2018
}

\section{Dijana Janković}

Court of Appeal in Niš, Republic of Serbia

\begin{abstract}
In the broadest sense, alternative sanctions are criminal law measures that substitute a prison sentence. They are practically parapenal sanctions considering that they lack the actual effectiveness inherent in classical punishment, which is expressed as a complete restriction of some rights or material values. The paper provides an overview of an international scientific-professional meeting of experts held at the Appellate Court in Niš, within the project "Strengthening the Probation and the Alternative Sanctions System in Montenegro and Serbia". Participants of the meeting were members of the Dutch delegation, as well as Serbian judges, public prosecutors, and probation officers. During the presentation of the project and the exchange of opinions and experiences on the application of alternative sanctions in both Netherlands and Serbia, numerous essential questions have been raised regarding the purpose of punishment, the achieved results, and the problems arising in everyday practice in the application of alternative sanctions.
\end{abstract}

Key words: alternative sanctions, imprisonment, parole, public interest, court, prosecution, probation.

Received March $3^{\text {rd }}, 2019 /$ Accepted March 11 $1^{\text {th }}, 2019$

Corresponding author: Dijana Janković, LL.D., Judge, Court of Appeal in Niš, Vojvode Putnika nn, Niš, Republic of Serbia; E-mail: dijankovic@gmail.com 


\section{INTRODUCTION}

Modern trends in combating crime are increasingly directed towards organized social activity of a preventive nature. This is reflected in strengthening and developing the attitude towards the perpetrators of criminal offenses in an attempt to resocialize them, strengthening special criminal law prevention, weakening the classical retributive element in punishment and, in general, and introducing changes in understanding the meaning and content of the awarded sentence. The notion of punishment, which used to be perceived as pure retaliation (i.e. punishment without a further aim) has evolved into the penalty aiming to achieve socially useful goals - protection of the society from crime through the reintegration of perpetrators and compensation of the victim.

The concept of alternative sanctions is based on the realization that multiple goals can be achieved through the implementation of these sanctions: the pronouncement of sanctions, the rehabilitation of the perpetrator, reparation of the damage done, as well as an active policy of assistance provided by society to a delinquent (McNeill, 2012: 12). It can be said that one of the essential goals of alternative sanctions is the suppression of recidivism, because they basically include measures and actions of a society that are aimed at the personality of the perpetrator, the perpetrator himself, his family and social environment, and deterrence (Bewley-Taylor, et all, 2018: 67). According to prior experience, recidivism commonly occurred after certain criminal behavior, which had been preceded by various criminal influences, when the personality of the perpetrator had already been largely affected by the severe consequences of earlier life, drug abuse and severe social conditions, as well as by the consequences of the committed crime and ultimately by prison conditions during the execution of the sentence.

Alternative sanctions entail a completely different idea. First of all, they provide an opportunity for the perpetrator not to be subjected to institutional treatment, which is very important for maintaining the sense of personal dignity and avoiding potential negative impacts. In this way, the community does not create resistance towards the perpetrator, and it is possible for the perpetrator to remain with his/her family, to perform regular business activities and earn income during the execution of an alternative sanction. At the psychological level, alternative sanctions have numerous positive effects on the perpetrator; they generate a sense of integrity in the community, develop a sense of responsibility, reintegration without isolation, active participation of the community in the execution, and securing the compensation of damage to the victim (Maruna, 2011: 673).

The ultimate accomplishment of the alternative sanctions application is to ensure that the measures of criminal law protection minimize the violation of human rights and one's dignity, and enable the maximum degree of restitution and elimination of harmful consequences of the criminal offense that affect both the victim and the entire society. In other words, it is to provide a balance in exercising the rights of the perpetrator, the rights of victims, and the interests of a society in safety and prevention of crime (Pitts, et al, 2014: 132). Contemporary views on alternative sanctions indicate that a global penal policy focuses on the perception that deprivation of liberty should be a sanction or a measure of the last resort (Global Prison Trends, 2018), which should apply only in case a prison sentence is really necessary (in felonies, crimes with elements of violence, minor victims, etc.).

Imprisonment is, therefore, considered as an option for the perpetrators who are at risk of recidivism, in serious criminal offenses, and in case of a need for treatment over a longer period of time. On the other hand, alternative sanctions should be applied to less- 
at-risk first-time perpetrators of minor offenses (Bergeron, 2017: 15). Alternative sanctions are one of the measures that are in line with what is described as "the third strike" in the modern criminal law science; they introduce the so-called consensualism into criminal law, in the sense that certain criminal cases are resolved in a non-custodial manner, by ensuring communication among three parties: the perpetrator, victims, and the court.

The term "alternative sanction" refers to any sanction imposed by a judicial or administrative authority, and any measure taken before or instead of a decision on a sentence, as well as to the means of enforcing the sentence of deprivation of liberty outside the prison facilities. There is a range of reasons in favor of alternative sanctions and against prison sentences in relation to the effects of crime and the community (UN Commission on Crime Prevention, 2018). Alternative sanctions:

- provide an opportunity for the perpetrator not to undergo institutional treatment,

- contribute to the preservation of a sense of personal dignity,

- reduce the occurrence of recidivism,

- enable avoiding the potential negative impacts of the prison environment,

- enable avoiding stigma and community resistance after the imprisonment,

- provide the opportunity to the person to remain within his family, and carry out his regular activities related to the workplace and earning income (Zeleskov et al, 2014: 25),

- create a sense of integration in the social community on a psychological level,

- develop a sense of responsibility and reintegration without isolation,

- enable active participation of the community in the execution of sanctions and decrease of the negative attitude towards the perpetrator of the criminal offense,

- provide a more secure compensation of damage to the victim,

- reduce community costs.

The judicial and prosecutor's office should be closely involved in the design and implementation of direct alternatives to imprisonment. This is provided in Recommendation (2000) 22 which recommends that judicial authorities should be involved in the process of devising and revising policies on the use of community sanctions and measures, and should be informed about their results, with a view to ensure widespread understanding of their nature in the judicial community $\left(\operatorname{Rec}(2000) 22\right.$, Appendix 2, point 7). ${ }^{1}$

According to the abovementioned basic course and respecting the basic principles of alternative sanctions in accordance with the intended purpose of punishment, an international scientific-professional meeting was held at the Appellate Court in Niš. The idea to hold the meeting of experts came from Dutch Project Manager Eva Erren, Center for International Legal Cooperation (CILC), and Koen Goei, Program Manager, Netherlands Helsinki Committee (NHC), as well as from judges and public prosecutors from the Netherlands. The meeting was held on the premises of the Appellate Court in Niš. This paper outlines the content of the meeting and the statements of the participants, with specific reference to the content and specificities of the Serbian and Dutch probation systems, the application of alternative sanctions in the two countries, as well as the conditions and opportunities for further improvement of the application of alternative sanctions in Serbia.

\footnotetext{
${ }^{1}$ Recommendation Rec (2000) 22 of the Committee of Ministers of the Council of Europe to member states on improving the implementation of the European Rule on community sanctions and measures, adopted, 29. Nov. 2000, Appendix 2 to Rec (2000) 22, Guiding principles for achieving a wide and more effective use of community sanctions and measures (point 7)
} 


\section{THE CONTENT OF THE INTERNATIONAL EXPERT MEETING AT THE COURT OF APPEAL IN NIŠ}

The international expert meeting on the application of alternative sanctions in court practice and probation services was held at the Appellate Court in Niš on $4^{\text {th }}$ December 2018.

The participants of the meeting were members of a delegation from the Netherlands, including: Tamara Trotman, Judge of the Appellate Court in the Hague (Netherlands); Marina Beun and Jan Hoekman, Public Prosecutors in the Hague; Koen Goei, Program Manager, Netherlands Helsinki Committee (NHC); and Eva Erren Project Manager, Center for International Legal Cooperation (CILC), as well as a number of domestic judges, public prosecutors, and probation officers, including: Dragan Jocić, President of the Appellate Court in Niš; Dijana Janković, Judge of the Appellate Court; Milica Zlatković, Judge of the Appellate Court in Niš; Jelena Miladinović, Judge of the Higher Court in Niš - Special Department for Combating Corruption; Mirko Drašković, Milica Grujić and Olgica Papović, judges of the Higher Court in Niš; Ivana Milovanović and Ana Vukotić, judges of the Basic Court in Niš; Andrija Ivić and Aleksandra Vujisić, public prosecutors at the Basic Public Prosecutor's Office in Niš; Aleksandar Stevanović, Public Prosecutor at the Special Department for Combating Corruption in Niš, Srećko Luković, Probation Officer at the Probation Agency in Nis (Execution of alternative sanctions at the Administration for execution of alternative sanctions of the Ministry of Justice of the Republic of Serbia), and Jelena Veselinović, a trainee at the Judicial Academy. ${ }^{2}$

The occasion for the meeting was the project titled "Strengthening the Probation and the System of Alternative Sanctions in Montenegro and Serbia", sponsored by the Dutch Ministry of Foreign Affairs and Partners from the Netherlands (CILC). The project

\footnotetext{
${ }^{2}$ The European Program for Human Rights Education for Legal Professionals (HELP) was created within the European Council of Europe's program for the education of legal practitioners to use the HELP methodology in the field of human rights. The presentation of the HELP course "Alternative Measures to Detention", dealing with alternative sanctions, was held on the premises of the Appellate Court in Niš on $22^{\text {nd }}$ May 2017. The course presentation at the Appellate Court in Niš was supported by the Council of Europe and the Human Rights Trust Fund (HRTF) within the framework of the Western Balkan Program in cooperation with the Judicial Academy of the Republic of Serbia. The course presentation was moderated by Dijana Janković, judge of the Appellate Court in Niš, HELP national mentor and lecturer. On this occasion, participants were presented with the HELP program, as well as the training resources available on the HELP e-Learning platform. The course presentation was attended by 70 judges and public prosecutors from the territorial jurisdiction of the Appellate Court in Niš, the Judicial Academy trainees, and representatives of the non-governmental sector. The introductory address was given by President of the Appellate Court in Niš, Judges Dragan Jocić, and Jasmina Krstenić from the HELP Advisory Board. After the opening remarks, the participants were addressed by Valentina Boz from the Directorate General for Human Rights and Rule of Law (DGI) of the Council of Europe, who introduced the participants with the methodology and training materials, and James Mec Manus, a member of the European Committee for the Prevention of Torture and Inhuman or Degrading Treatment (CPT) from the United Kingdom. Then, Dijana Janković introduced the participants with the syllabus of the HELP course "Alternative Measures to Detention", developed in cooperation with the UN Office on Drugs and Crime (UNDOC), which is aligned with the Serbian legal system. The presentation also marked the opening of the online course, which was accessed via the HELP elearning platform. The course was interactive and contained various practical exercises to enable the acquisition of relevant knowledge and skills.

On $25^{\text {th }}$ April 2018, the Appellate Court in Niš hosted the opening of another HELP course for judges and public prosecutors, within the Council of Europe HELP Project titled "Explanation of Criminal Judgments". The event was attended by Mirjana Lazarova Trajkovska, Judge of the European Court of Human Rights from Macedonia, who introduced the participants with the practices and standards of the European Court of Human Rights. The course lasted seven weeks, and it was facilitated by Dijana Janković, Judge of the Appellate Court in Niš.
} 
included the following project participants: the Netherlands Helsinki Committee (NHC), the Center for International Legal Cooperation (CILC), the Civic Alliance (CA), Juventas, the Belgrade Center for Human Rights (BCHR), Neostart, the Minister of Justice in Serbia, the Judicial Academy in Serbia, the Minister of Justice in Montenegro, the Judicial Training Center in Montenegro, the Dutch Prosecution Service, the Dutch Probation Service, the Council for the Judiciary. The overall objective of the project is to contribute to the efficient and professional functioning of the criminal justice sector in Serbia and Montenegro.

The moderators of the meeting were Eva Erren Project Manager (CILC) and Dijana Janković, Judge of the Appellate Court in Nis, who had previously completed the training course in the Hague on the topic "Detention and Alternative Sanctions". ${ }^{3}$

The aim of the meeting was to review the possibilities and modalities of applying alternative sanctions in criminal proceedings and in the procedure for the execution of criminal sanctions, to familiarize the participants with the project, and to enable exchange of practical knowledge and experience between judges and public prosecutors from the Netherlands and Serbia.

In the introductory address, Dragan Jocić, President of the Appellate Court in Niš, opened the meeting, greeted the participants, and presented the basic postulates and results of the penal policy in Serbia.

On behalf of the Center for International Legal Cooperation (CILC), the participants were addressed by was Eva Erren, Project Manager (CILC), who co-managed the project "Strengthening the Probation and the System of Alternative Sanctions in Montenegro and Serbia“" with Koen Goei. In her introductory speech, Eva Erren emphasized that probation officers, prosecutors and judges, as well as lawyers, should work together. She focused on the basic purpose and goals of the project, stating that the proposed project aimed to enforce the judiciary and the rule of law in Serbia and Montenegro by stimulating and supporting the probation services and the alternative sanctions system to be more effective and widely used. The intended long-term project impacts include a viable reduction of overcrowding in correctional institutions through a more proper use of alternatives to imprisonment, as well as a decrease in recidivism as a result of more efficient pre- and post-penal supervision and active support for successful reintegration.

The Probation Services have a very limited time for supervising conditional sentences (probation) and conditional release (parole), and for implementation of community service sentences. More specifically, the overall objective of the project is to contribute to the effective and proficient functioning of the criminal justice sector in Montenegro and Serbia, where the main actors in the judicial chain (probation, penitentiary, prosecutors and judges) cooperate with each other and with civil society organizations (CSO's). This is closely related to the objectives of the Matra 2017-2020 framework, which aims to strengthen the rule of law, and is also in line with the Copenhagen Criteria. The action is partly a followup of the project "Support to the Probation Service and the Alternative Sanctions System in Montenegro", implemented by the NHC and the CILC from 2014 to $2017 .^{4}$

\footnotetext{
${ }^{3}$ The course "Detention and Alternative Sanctions" was organized by the Leiden Law School, the Netherlands Helsinki Committee, and the Hague Academy for Local Governance. This course was held in the Hague, from $4^{\text {th }}$ to $11^{\text {th }}$ October 2018, and it was facilitated by the Netherlands Ministry of Foreign Affairs under the Matra Rule of Law Training Programme.

${ }^{4}$ The Netherlands Helsinki Committee (NHC), Center for International Legal Cooperation (CILC), Project Strengthening the Probation and the System of Alternative Sanctions in Montenegro and Serbia -Summary, Duration 01.09.2017-31.12.2020.
} 
In the introductory remarks, Dijana Janković, a judge of the Appellate Court in Nis, emphasized the importance of alternative sanctions in penal policy. She pointed out that alternative sanctions had primarily been applied in cases involving the commission of minor criminal offenses, in cases involving primary perpetrators (first-time offenders) and in cases involving perpetrators from the so-called "vulnerable groups" (women, children, persons with mental illness, drug addicts, elderly prisoners, foreign prisoners, persons with disabilities). She also pointed to a large number of short-term imprisonment sentences in Serbia, instead of which alternative sanctions could have been claimed. According to the latest data from the Department for treatment and alternative sanctions at the Administration for the Execution of Alternative Sanctions of the Ministry of Justice of the Republic of Serbia, about 18,692 alternative sentences were pronounced in Serbia in the period from 2006 to 2017. The data show a rise in the number of alternative sanctions imposed in Serbia, although some alternative sanctions were imposed in a far greater number than others. Thus, the statistics show that there was a constant increase in the "house imprisonment" since the time it was introduced in the legislative system in 2011 until 2017 (a total of 394 sentences in 2011; 882 sentences in 2012; 1101 sentences in 2013; 1934 sentences in 2014; 2498 sentences in 2015, 3136 sentences in 2016; and 3362 sentences in 2017). Janković welcomed the attendees, especially the guests from the Netherlands, wishing them successful work and a pleasant stay.

After the introductory statements, Andrija Ivić, a Public Prosecutor, Mirko Drašković, a Judge of the Higher Court in Niš, and Srećko Luković, a Probation Officer, presented their experiences in the application of alternative sanctions in the Republic of Serbia, the problems they encountered in their practice and the achieved results.

Then, the representatives of the Dutch delegation Tamara Trotman, a Judge of the Appellate Court in the Hague, and Marina Beun and Jan Hoekman, Public Prosecutors in the Hague, introduced the attendees with the basic settings of the application of alternative sanctions in the Netherlands, their results and work methodology. Eva Erren, Project Manager (CILC), briefly presented the Project and the results expected after its implementation.

Andrija Ivić, Deputy Public Prosecutor in Niš, introduced the participants with the Basic Public Prosecutor's Office in Niš and the application of alternative sanctions in the preinvestigation proceedings. ${ }^{5}$ He noted that, according to the Criminal Procedure Code (CPC) of of the Republic of Serbia, the pre-investigation stage begins with filing a criminal complaint and is supervised by the public prosecution. The Criminal Procedure Code mandates that prosecutors assume responsibility for conducting criminal investigations. Their involvement in the early stages of decision-making, especially their decisions on issues concerning detention, has the potential to ensure that only the strongest cases proceed to investigation; most importantly, it demonstrates a more thoughtful use of detention, which could reduce the overcrowding in penitentiary facilities, and a more efficiently

\footnotetext{
${ }^{5}$ The current trend in Serbian criminal procedure system obviously concerns the leading role of public prosecution services in out-of-court settlements. The Serbian Criminal Procedure Code (hereinafter: CPC), Official Gazette RS, 72/11, 101/2011, 121/2012, 32/2013, 45/2013, 55/2014, came into force in 2011 but has been applied in courts of all jurisdictions since October 2013. The CPC sets forth 3 basic stages of the Serbian criminal procedure: (1) Pre-trial Proceedings (Pre-investigation, Investigation and Indictment); 2) Main Hearing in First Instance Proceedings (Preparatory Hearing, Main Hearing, Pronouncing and Proclamation of the Judgment); and 3) Legal Remedies Proceedings. Notably, this classification does not include the procedure for extraordinary legal remedies and special procedures.
} 
streamline criminal matters through the continuum of the process. The public prosecutors decide on individual cases. However, by applying new powers, such as transaction fines, public prosecutors to a large degree create and implement criminal policies relating to general approaches adopted for certain types of crimes.

Andrija Ivić also pointed out that, in the field of alternative sanctions in the preinvestigative phase, the Public Prosecutor's Office mostly applies the provision of Article 283 CPC, stipulating the conditions for the application of the institute of deferring criminal prosecution. ${ }^{6}$ Deferring criminal prosecution is applied only in the pre-trial process in the pre-investigation stage. The prosecutor has a considerable discretion over crimes punishable by less than five years and may defer prosecution upon the defendant's agreement to compensate for any harm that he has caused and to satisfy other law-abiding life conditions that the prosecutor may propose (Article 283 paragraphs 1 and 2 CPC). However, there are still many open questions regarding the most important issue: sentencing discount and the size of discounts that can be offered in exchange for consenting to out-of-court proceedings.

According to the practice of the Basic Public Prosecutor's Office in Niš, the most common criminal offense in the application of the institute of deferring criminal prosecution is causing danger in public traffic (Article $289 \mathrm{CC}$ ), in cases involving minor bodily injuries. A total of $70 \%$ of orders for deferring criminal prosecution were issued for the commission of this criminal offense, as compared to the total number of cases in which criminal prosecution was postponed during 2013 and 2014.

In particular, Ivić pointed out that the obligation to undergo psychosocial treatment in order to eliminate the causes of violent behavior proved to be most effective in criminal offences of violent behavior and domestic violence. In this respect, the program implemented in the Social Work Center in Niš yielded very good results. Unfortunately, this program has been suspended due to the lack of funds for its further implementation. In addition to the institute of deferring criminal prosecution, the public prosecution offices have been applying the institute of a plea bargaining agreement to a considerable extent.

Mirko Drašković, Judge of the Higher Court in Niš, pointed out that the legal institute of alternative sanctions was a relatively recent development in domestic criminal law. For example, the penalty of community service was introduced into Serbian criminal law on $1^{\text {st }}$ January 2006. Prior to that, domestic criminal law did not recognize either this type of punishment or a number of other alternative sanctions. At first, the introduction of alternative sanctions was not followed by adequate legislation that would enable the enforcement of new types of criminal sanctions, even if the courts pronounced them. Practically, alternative sanctions have begun to be implemented more intensively in Serbia since 2010. Given that alternative sanctions can be imposed on minor offenses, the

\footnotetext{
${ }^{6}$ Article 283 para. 1 CPC provides:

"The public prosecutor may defer criminal prosecution for criminal offences punishable by a fine or a term of imprisonment of up to 5 years if the suspect accepts one or more of the following obligations:

1) to rectify the detrimental consequence caused by the commission of the criminal offence or indemnify the damage caused;

2) to pay a certain amount of money to the benefit of a humanitarian organization, fund or public institution;

3) to perform certain community service or humanitarian work;

4) to fulfill maintenance obligations which have fallen due;

5) to submit to an alcohol or drug treatment programme;

6) to submit to psycho-social treatment for the purpose of eliminating the causes of violent conduct;

7) to fulfill an obligation determined by a final court decision, or observe a restriction determined by a final court decision." (CPC, Official Gazette RS, 72/11, 101/2011, 121/2012, 32/2013, 45/2013, 55/2014)
} 
High Court in Niš (which is responsible for adjudicating the most serious crimes) does not have many opportunities to impose alternative sanctions. However, the High Court is competent to deal with juvenile perpetrators of criminal offenses and thus the High Court is a relevant forum for the application of alternative sanctions. Judge Drašković especially emphasized the application of Art.14 para. 2 of the Act on Juvenile Offenders and Criminal Protection of Juveniles, which prescribes obligations that can be imposed on juvenile criminal offenders in conjunction with the pronounced court reprimand, or independently. He noted that the use of alternative sanctions is useful and important because their pronouncement reduces not only the costs of the state but also the prison population, the prisoners' stigma (who in this case do not break their relations with their family, work, school, or everyday routine). He also emphasized the need for better education of the judiciary and the general public alike. It happens that the public, in some cases, reacts violently and with disapproval if an alternative sanction is imposed instead of a sentence of imprisonment. In addition, it would be significant to create conditions for greater application of community service penalties.

Srećko Luković, Probation Officer in Probation Agency in Niš, informed the attendees that the Probation Office in Belgrade was first office which started operating in 2010. It is one the seven probation offices which were later established in the territory of all High Courts in the Republic of Serbia. In Niš, there is only one probation officer, employed on a full-time basis. The Probation Office in Niš also employs three prison officers, who concurrently work at the Criminal Correctional Facility in Niš.

Luković noted that the most commonly awarded alternative sanction he had encountered in his practice was the so-called "house imprisonment" ${ }^{7}$, stating that 80 of these sentences were being executed at the time ( 31 by using electronic surveillance and 49 without the use of electronic surveillance). However, a total of 200 judgments in which a "house imprisonment" sanction was pronounced are still pending enforcement, while 20 of them are processed as "urgent cases" because the judgments were pronounced in 2015 but still have not been enforced. The reason for this procrastination is the lack of electronic surveillance devices. The number of electronic surveillance devices at the disposal of the Probation Service in Nis is insufficient for the number of cases pending execution. The judges have been informed about this problem and now this criminal sanction is most often pronounced without the use of electronic surveillance. From the point of view of achieving the purpose of punishment, the delay raises the question of the effectiveness of the execution of these alternative sanctions three years after being pronounced.

As for the security measures aimed at ensuring the presence of the defendant in court and uninterrupted operation of criminal proceedings, ${ }^{8}$ the prohibition of leaving a dwelling

\footnotetext{
${ }^{7}$ When defining the punishment of imprisonment in Article 45, the Criminal Code RS (hereinafter: CC), Official Gazette RS, 85/2005, 88/2005, 107/2005, 72/2009, 111/2009, 121/2012, 104/2013, 108/2014, 94/2016, specifies that this punishment may also be executed in the premises where the offender lives, provided that it does not last for more than one year and that his personality, previous life, behaviour after the commission of criminal offence, degree of guilt and other relevant circumstances suggest that the purpose of punishment can be accomplished in that way. This modality of execution of prison sentence cannot be applied to an offender who committed an offence against marriage and family if the offender and the victim live in the same household.

${ }^{8}$ It is possible for the court to utilize measures other than detention to secure the presence of the defendant and to ensure the unobstructed conduct of criminal proceedings (Article $188 \mathrm{CPC}$ ). The Criminal Procedure Code of the Republic of Serbia provides: prohibition of approaching, meeting or communicating with a certain person; prohibition of leaving a temporary residence; bail; the prohibition of leaving a dwelling (house arrest).
} 
or so-called "home detention" (house arrest) ${ }^{9}$ has been increasingly imposed. Since 2010, a total of 44 measures of "home detention" have been imposed. Currently, there are 3 home detention measures are being executed, 2 of which are without electronic control.

When it comes to community service, ${ }^{10} 11$ community service sentences are currently underway, while 40 sentences $^{11}$ are pending. Since the establishment of the Probation Office in Niš, a total of 220 community service penalties have been executed. The Probation Office in Niš has agreements on cooperation with public utility companies and institutions in the territory of the City of Niš. As a curiosity, Luković notes that the Basic Court in Aleksinac has not awarded any community service penalties, as compared to a considerable number of pronounced sentences of "home detention" (house arrest).

In case of a conditional release ${ }^{12}$ with supervision ${ }^{13}$, Luković pointed out that probation officers have the highest competences when executing this measure because they are actively involved in the case at issue.

Considering that the application of the conditional release with supervision began in 2018 , nine cases have been received for enforcement so far, five of which have been enforced. There were problems in the enforcement in the remaining cases. In particular, post-penal acceptance is difficult to implement, although there is a pilot project that is in stagnation now. Luković stated that they were currently supervising a measure of prohibition of approaching, meeting or communicating with a specific person. Regarding the enforcement of alternative sanctions, their work has been slowed down to some extent due to personnel and equipment problems reflected in an inefficient number of probation officers, an inefficient number of electronic surveillance devices, irregular communication with prosecutors and the court, etc.

\footnotetext{
${ }^{9}$ To ensure compliance with the prohibition of leaving a dwelling (house arrest), the court may also decide to order the wearing of a location tracking devices, or reporting to the police (Article $19 \mathrm{CPC}$, on house arrest), or seizure of driver's license or travel documents (Article 199 CPC, on the prohibition of leaving a temporary residence).

${ }^{10}$ Article $52 \mathrm{CC}$ prescribes that community service may be imposed on the offenders who committed criminal offences punishable by a term of imprisonment of up to three years or a fine. It defines community service as any kind of socially acceptable and useful work that does not offend human dignity and that is not performed with the intention to obtain material (financial) benefits.

${ }^{11}$ When deciding whether to impose this punishment, the court is obliged to take into account the purpose of punishment (i.e. general and special prevention), the type of committed criminal offence, the personality of the offender and his willingness to perform community service. It is important to mention that community service cannot be imposed on the offender without his consent. If the offender fails to fulfil all the obligations imposed within the punishment of community service, the court is entitled to replace this punishment with imprisonment. ${ }^{12}$ Conditional release (parole) can be implemented if the prisoner has served two thirds of punishment, provided that his behavior has improved during the enforcement of punishment to the extent that it may be reasonably expected that he will behave properly after the release and that he will not re-offend, particularly in the period before the punishment is served. Other circumstances suggesting that the purpose of punishment has been accomplished are also taken into consideration. The prisoner who attempted or managed to escape from prison cannot be granted conditional release. The decision on conditional release is made by the court. When deciding on conditional release, the court takes into account the following circumstances: behavior of the prisoner during the enforcement of prison sentence, fulfillment of his working obligations depending on his capacity as well as other circumstances showing that the purpose of punishment has been achieved. In the decision on conditional release, the court may order the offender to fulfill some other obligations, such as those referring to conditional sentence with intense supervision. If the court does not revoke conditional release, it will be considered that the offender has served his punishment in total (Article 46 CC).

${ }^{13}$ Article 44 of the Act on Execution of Non-Custodial Sanctions and Measures (Official Gazette RS, 55/2014, 87/2018) stipulates that the supervision of a suspended person is carried out by the Probation Service if the court has determined in the decision on conditional release that the convicted person is obliged to fulfill one of the following obligations:1) report to the authority competent for the execution of the protective supervision, 2) complete a training program for a particular occupation; 3 ) accept employment corresponding to his abilities, etc.
} 
Dijana Janković, Judge of the Appellate Court in Nis, noted that communication between courts, prosecutors and commissioners was very important. The practice of providing judges and prosecutors with reports on the defendant's personality in the course of criminal proceedings does not exist. It would be useful for the court to obtain such reports (e.g. from the probation service) before deciding on the type and degree of the sentence (i.e. before the completion of the main trial) and before the decision on conditional release.

With regard to conditional release (parole), the current practice in the Republic of Serbia is that courts decide on conditional release on the basis of: 1) reports of a prison institution in which the convicted person is serving a prison sentence; 2) extracts from the criminal records of the competent Police Directorate on the previous convictions of the perpetrator; 3 ) examining the case files including a final judgment on the basis of which the convicted person serves a sentence of imprisonment and on the basis of which the decision on conditional release is to be made; and 4) recommendation of the public prosecutor regarding conditional release (whereby it is common practice of public prosecutors in Serbia to give a negative opinion in terms of conditional release, and suggest the rejection of the application of conditional release). However, in some cases, the aforementioned reports and the available information to the court when deciding on a request for conditional release are not sufficient for the court to attain a true picture of the current situation of the convicted person, his/her personal circumstances and his/her personality. In the absence of additional information, it appears that the court is more guided by the information related to the previous period. The reports and information about the convicted person related to the period when the request for conditional release is taken into consideration would be more relevant to the court. This is important in terms of the assessment of the influence of the conducted treatment on the convict during the enforcement of the prison sentence and the extent of the risk of recidivism after release from the prison institution.

Eva Erren, Project Manager (CICL), thanked the presenters for the insightful accounts into the state of affairs in the Republic of Serbia regarding the application of alternative sanctions. Then, members of the delegation from the Netherlands gave a brief overview of the application of alternative sanctions in the Netherlands.

Tamara Trotman, Judge of the Appellate Court in the Hague, expressed gratitude for the meeting with colleagues from the Republic of Serbia. She said that the Netherlands had 17.1 million inhabitants, twice as much as the Republic of Serbia, and 2.500 judges. The Criminal Procedure Code of the Netherlands prescribes that the judgment should state the reasons for the suspension of the sentence, or why an alternative sanction is pronounced. As compared to the Dutch legislation, the purpose of punishment in the Republic of Serbia is more fully described in Article 42 of the Serbian Criminal Code, which obliges the judge to consider the purpose of the sentence for a particular person in a particular case.

Therefore, Trotman considers that it is important to be provided with relevant information about the accused person (his personality, family and social circumstances). In the Netherlands, the reports on the personality of the defendant are received from the competent prosecution service and the law allows the prosecutor or judge to use the data thus obtained before deciding on the type and amount of the criminal sanction. The Probation Service provides data in a specific format, which allows them to easily review the report and notice the most important information. The report also lists the risks and safeguards that the Probation Officer observed from the interviews with the convicted person and persons from his immediate environment, as well as the issues of accommodation, education, social relations, employment, etc. Dutch judges consider probation reports useful information. 
Probation officers have more time than judges to obtain relevant information about the personality of the accused. Relevant information considers: risk factors, relation problems, mental disorders, financial situation, work, alcohol/drug abuse as well as the attitude of the accused, motivation to change, risk of reoffending. ${ }^{14}$

In 2017 alone, suspended sentence and community service penalty were pronounced in more than 20,000 cases. Likewise, out of 1,020 judgments, the sentence of imprisonment was pronounced in $36 \%$ of cases, while the sentence of community service was pronounced in $32 \%$ of cases. ${ }^{15}$ The recommendations given by the Council of Ministers of the European Union on the community service sentence that could be used in terms of resocialization are applied in the Netherlands. Since 2001, community service is one of the main penalties, which according to the law cannot last more than 240 hours and must be executed within 12 months from the moment of pronouncing the sentence.

Since 2012, restrictions have been imposed on pronouncing the community service for violent and sexual offenses (which are subject to higher sentences); before that, there were no restrictions, unless this sentence was combined with the sentence of the imprisonment. Also, community service cannot be pronounced if, after a conviction on community service, the offender commits a new criminal offense within a period of five years. Therefore, in case of recidivism after the enforcement of the community service sentence, this sentence cannot be re-imposed within 5 years.

Regarding the suspended sentence, Tamara Trotman clarifies that in the Dutch legislation it can be completely or partially suspended, whereas the judgment specifies the conditions which are to be fulfilled within the period of time not longer than 3 years (but in the practice it is usually 2 years). This type of punishment is mostly pronounced in case of serious bodily injuries and, under the law, a suspended sentence may be imposed for crimes punishable by a sentence of imprisonment of up to 4 years. Of course, there is always a general requirement not to commit a new criminal offense, while the probation officer and his report have a significant role in imposing special conditions.

Marina Beun, Public Prosecutor in the Hague, notes that the Probation Service in the Netherlands is in charge of enforcing both protective surveillance measures and alternative sanctions. The prosecutor's office and the probation service are in constant contact. The probation service contacts the prosecutor's office if a problem in the realization of the sentence occurs. Each prosecutor's office has a department for suspended sentences, where the most favorable solution for each convicted person is discussed. Sometimes more support is needed for the successful enforcement of alternative sanctions and imposition of obligations, and if a person fails to comply with the set conditions and obligations, the alternative sanction

\footnotetext{
${ }^{14}$ On $10^{\text {th }}$ October 2018, at Matra Rule of Law Training Programme in the Hague, Nico Tuijn, Deputy Chief of Justice at Court of Appeal, Senior Justice Court of Appeal, Hertogenbosch, the Netherlands, pointed out that probation is often viewed as a "soft option". A deprivation of liberty implies not only imprisonment but also many obligations of a conditional sentence (treatment, geographical restrictions)". Community sentence entails 240 hours of work, a deprivation of liberty for many weeks and a strict regime of working for the good cause.

${ }^{15}$ In his lecture on the topic “An introduction to the Dutch probation practice” given at the course „Detention and Alternative Sanctions (Matra Rule of Law Training Pregramme) in Veenhuizen, the Netherlands, on 7th October 2018, Frans Clobusa, the Dutch international probation trainer, pointed out that the probation service in the Dutch system, as an independent service, in cooperation with the prosecution, represents a permanent link in the judiciary sistem. He stated that, in 2017, the Netherlands courts pronounced a total of 28,613 community service sentences and 17,313 suspended sentences, protective supervision, and conditional release orders. He also noted that the purpose of the sentence of electronic surveillance is not imposed to influence the perpetrator's behavior but only as a measure of the enhanced control.
} 
is replaced by imprisonment. The prosecutor is the one who makes recommendations, and the judge decides on the sentence. Protective surveillance measures usually last for 3 years and the probation officer informs the prosecutor whether the measure has been enforced and whether the conditions determined by the court in the judgment have been completely met. If there are problems and the convicted person does not fulfill the given obligations, the alternative sanction is replaced by a prison sentence but the convicted person has the right to object to that decision and then the objection is discussed.

Jan Hoekman, the Appellate Public Prosecutor in the Hague, introduced the participant with his experience in working at the Probation Department for long-term imprisonment. He notes that about 2,000 people are employed in the probation service in the Netherlands, or more precisely, 1,900 officers working on reports, not including administrative staff. He obtains all the data on a particular case on the basis of reports received from the probation service. The reports contain even suggestions on further treatment of a particular person (specifically proposals regarding the type of measure or sanction), for example, whether a measure of medical treatment should be imposed, and alike. Every month, he receives reports on sensitive cases, whether or not conditions for release are fulfilled. Hoekman presented a particular case from his practice and explained the procedures as well as the steps taken to solve the case in the most favourable way for the convicted person. ${ }^{16}$

Hoekman also states that the probation is not recommended to be granted in only $10 \%$ of cases, due to the offence circumstances or risk assessment. He points out that it is incomparably easier to deal with the conditional release when the person is under surveillance. The Netherlands has a service dealing with this issue. The Probation Officer notifies the competent authority of any offense committed by a person while on conditional release. In short, the probation service takes care of the convicted person and sends notifications to the prosecution. The Prosecution also gives a proposal on the measures that a convicted person released on parole is obliged to fulfill.

Srećko Luković, Probation Officer in the Republic of Serbia, notes that in the Republic of Serbia there are 20 probation officers and 10 administrative officers, who are assisted by other 50 administrative officers from the criminal correctional facilities and district prisons. The Probation Service in Serbia does not have special cooperation with the Prosecutor's Office, nor does it provide the Prosecutor's Office with reports. The number of cases

\footnotetext{
${ }^{16}$ In his lecture on the topic "The Dutch Probation in European Perspective" at Matra Rule of Law Training Programme - Detention and Alternative Sanctions, held in the Hague on 8th October 2018, Leo Tigest, Consultant in Community-based Justice, pointed out that the functions of a pre-sentence reports are to provide courts with objective information about the offender and about the suitability of various sentencing options, to contribute to the fairness of the decision by the court as perceived by the offender, to enhance the acceptance of a sentence and contribute to a lower reconviction rate, to help the justice system to make optimal use of the array of sentencing options, and to contribute to economic savings if the right offender is matched with the least costly and most effective sentence. Likewise, the minimum content of the reports usually contain: offence analysis and pattern of offending: relevant offender's circumstances as either a contributing factor or a protective factor of offending behavior; risk of harm and likelihood of reoffending analysis based on data and clinical judgment: outcome of presentence checks with other agencies or providers of probation services; address of any indications of possible sentence provided by the court; an integral conclusion on the crime-related factors and what has to be done: sentence proposals commensurate with the seriousness of the offence, addressing the offender's assessed risk and needs, and what kind of sentence will work. For Dutch and UK judges and public prosecutors, the work process is unimaginable without pre-trial reports reports from the Probation Service. They do not feel comfortable to make a decision without the information on risk (crime related and protective factors), opportunities and suitability of alternative sentencing options. (“Am I making the right decision?"). Pre-sentence reports are a pathway for judges to use cheaper, more effective, proportionate alternative sanctions.
} 
arriving for enforcement to the probation service is progressively growing, but the enforcement is complicated because there are only 1,200 electronic surveillance devices, 300 of which are constantly out of use due to repair. The role of the probation officer in Serbia is to inform the court about the enforcement of the sentence at the end of the enforcement procedure; besides that, there is no other communication either with the courts or prosecutors.

Ivana Milovanović, a judge of the Basic Court in Niš, notes that one of the problems in the execution is that a person sentenced to the so-called "house imprisonment") in Serbia is not subjected to any institutional treatment program in the process of execution of the sentence (in his dwelling place), whereas each convicted offender serving a prison sentence is obliged to participate in such a program. In practice, the opinion of the probation service on a prisoner in "house imprisonment" is reduced to whether such a person has left the dwelling place or not; the other mechanisms for this alternative sanction do not exist.

Milovanović also notes that Serbia has adopted the Action Plan for Implementation of the Strategy of Developing the System of Execution of Criminal Sanctions in the Republic of Serbia until 2020. ${ }^{17}$ She points out that the Action Plan is a set of precisely defined activities aimed at the implementation of the measures from the Strategy related to: legislation and regulations, infrastructure, respect for the human rights of persons deprived of their liberty, protection of particularly vulnerable categories, treatment and health protection of persons deprived of their liberty, security, training and professional training of the convicted offenders, alternative measures and sanctions, social reintegration and postpenal acceptance, professional training of employees in the system of execution of sanctions, etc. Human resources and their initial and ongoing trainings are also envisaged.

In relation to the aforesaid, Milovanović addressed the question of restorative justice. She emphasized that restorative justice today finds its application in various areas, contexts and situations: in the field of criminal justice, for resolving conflicts in schools, at the workplace, at the local community level; in family, commercial and property disputes, etc. From the point of view of the criminal justice system, restorative justice can occur in several forms: as a form of diverting criminal proceedings (diversion measures), as a type of sanction (alternative sanction) or part of existing criminal sanctions, and as part of the treatment of persons serving institutional sanctions. Thus, one of the possibilities of applying restorative justice is the introduction of restorative approaches to prisons or other institutions where institutional criminal sanctions are being implemented. She believes that restorative justice can bring more humanity into the penal system and help in the treatment of convicted persons and their preparation for the release. In addition, the involvement of victims in restorative programs contributes to increase of the victim visibility, which is often marginalized in the criminal justice system. She referred to a restorative justice program developed at a prison in Hamburg, Germany (Hagemann, 2003: 224-229). It is intended for adult perpetrators of more serious crimes, such as murder, drug trafficking, robbery, fraud and severe forms of assault on other persons. She also mentioned another program aimed at raising the awareness of prisoners about the

\footnotetext{
${ }^{17}$ The Action Plan for Implementation of the Strategy of Developing the System of Execution of Criminal Sanctions in the Republic of Serbia until 2020, Official Gazette RS, 85/2014. On 23 ${ }^{\text {rd }}$ December 2013, the Government of the Republic of Serbia adopted the Strategy of Developing the System of Execution of Criminal Sanctions in the Republic of Serbia until 2020.
} 
impact of crime on the victim and the community, as well as their empowerment to accept responsibility for their actions - the Sycamore Tree program (Van Ness, 2007: 313; Johnstone, 2014: 6-7). This program is applied in about 40 prisons in England and Wales, to both juveniles and adults, as well as to persons of both sexes. In 2011, this program was implemented in prisons in 27 countries around the world. She asked the guests from the Netherlands about the program on the treatment of persons serving a "home prison" sentence in the Netherlands, what kind of novelties the program offered, and whether the restorative justice was applied.

Tamara Trotman, Judge of the Appellate Court in the Hague, stated that the program of restorative justice was something new in Dutch practice. There were several pilot programs on mediation in criminal legislation.

Koen Goei, Program Manager (NHC), noted that there is an organization dealing with restorative justice and mediation, but it deals with victim assistance and is separate from state authorities. In the Netherlands, restorative justice is something that deals with social organizations rather than a judicial system. He asked the colleagues from Serbia to explain how mediation was organized in Serbia.

Milica Zlatković, Judge of the Appellate Court in Nis, informed the participants that the Basic Court in Niš and the High Court in Niš are the only courts in Serbia that apply mediation and that they have good results, even in those cases that are in the process of appeal. They also had one case of a criminal offense that was subject to mediation, which was successfully resolved by Dijana Janković, who acted as a mediator in the case.

Dijana Janković, Judge of the Appellate Court in Niš, mentioned that the mediation procedure was regulated in Serbia by a special Act on Mediation in Dispute Resolution. ${ }^{18}$ Mediation is particularly possible in property lawsuits (involving the performance of an obligation), in family matters, commercial disputes, administrative matters, and in all other disputes where mediation is considered to be suitable, given the nature of the dispute. Pursuant to the Act on Mediation in Dispute Resolution, mediation is applied in criminal and misdemeanor cases in respect of property claims and claims for damages.

The parties may initiate the mediation procedure before or after the court proceedings have been initiated. In practice, after the court proceedings have been initiated, it is most frequently the judges adjudicating civil and criminal matters in the courts of ordinary jurisdiction who refer cases to mediation. In such a case, mediation is carried out by a mediator, who holds a license from the Ministry of Justice and is registered in the Mediators Register of the Republic of Serbia. The parties have the right to choose a mediator from the list of mediators of the Republic of Serbia. A mediator may or not be a judge. In the Basic and Higher Court in Niš, the Mediation Center has been very successful and has achieved significant results. The intention is to include not only civil cases but also e criminal cases in the mediation process. In criminal cases, the mediation procedure is carried out primarily in cases where the procedure is initiated by filing a private criminal complaint (i.e. a complaint of a private prosecutor for minor offenses, and not at the request of the public prosecutor). On the other hand, the Criminal Code of the Republic of Serbia includes the institute of "Settlement of the offender and victim"19, which deals with minor offenses.

\footnotetext{
${ }^{18}$ Act on Mediation in Dispute Resolution, Official Gazette RS, 55/2014.

${ }^{19}$ Article 59 CC, "Settlement of the Offender and Victim", stipulates that the court may remit from punishment the perpetrator of a criminal offence punishable by up to three years' imprisonment or a fine if the offender has fulfilled all his obligations from an agreement reached with the victim. The Serbian criminal law is consistent with Rec (2000) 22, par.1 in relation to the introduction of the provisions in Art. 58 par. 3 CC which provides
} 
Over the past decade, the reforms in the criminal (substantive, procedural and enforcement) legislation and juvenile legislation in Serbia have resulted in numerous novelties regarding the attitudes towards perpetrators of crime, including setting the foundation for the introduction of elements of restorative justice as a response to the crime of adolescents and juveniles. As Judge Ivana Milovanović mentioned, we are familiar with the experiences of other European countries that apply the principles of restorative justice, especially during the enforcement of prison sentences. For example, since 2000, each prison in Belgium had a "restorative justice advisor" (Aertsen, 2006: 73). The essence of this approach is that the entire prison system is supported to "develop culture, skills and programs that provide space for the needs of victims and restorative responses". This should be considered in the future development of penal and prison systems. Judge Milovanović also added that, in criminal matters, mediation may be used in crimes prosecuted on a private complaint for minor offenses; thus, judges of the Basic Court in Niš practice this because these cases concern personal (private) disputes (which are not prosecuted by the prosecutor), where mediation can lead to the settlement of a dispute.

Tamara Trotman, a judge at the Appellate Court in the Hague, raised the question whether the legislation of the Republic of Serbia allows for the application of the institute of deferring criminal prosecution or the imposition of the community service sanction for the criminal act of domestic violence.

Andrija Ivić, a Deputy Public Prosecutor in Niš, noted that the Criminal Code of the RS generally allows the implementation of these institutes for the basic form of domestic violence (taking into account the prescribed punishment for the criminal offense of domestic violence Article 194 par. 1 and 2 CC and the general conditions prescribed by the provision of Article 283 of the CPC for the deferring of criminal prosecution). However, the Act on the Prevention of Domestic Violence and the General Obligation of the State Prosecutor explicitly exclude the deferring of criminal prosecution, psychosocial treatment and community service. For severe (qualified) forms of criminal offense domestic violence, it is not possible to apply the institute of deferring criminal prosecution or community service punishment because stricter penalties are stipulated for these forms of offences.

Aleksandar Stevanović, a Deputy Public Prosecutor in the Special Department for Combating Corruption, specified that a prosecutor is subject to disciplinary responsibility if he does not act in compliance with the Instruction. These institutes were applied in 2012 and 2013 , and $80 \%$ of beneficiaries of psychosocial treatment did not appear as recidivists.

Srećko Luković, a Probation Officer, presented the statistics that the sentences of the home imprisonment ranged from 4 months to 8 months on average, while the length of "home detention" (house arrest) was significantly longer. There were cases in which the measure of "home detention", which is only a measure that secures the defendant's presence in the criminal proceeding, lasted for 2 or even 3 years. With regard to alternative sanctions, community service may last up to 360 hours in the Republic of

exemption from penalty and Article $59 \mathrm{CC}$ which provides for settlement of the offender and victim. Likewise, Article 59 par. $3 \mathrm{CC}$, „Remittance of Punishment”, stipulates that the court may also remit from punishing the perpetrator of a criminal offence punishable by imprisonment of up to five years, provided that after the commission of the offence and before learning that he has been uncovered, he should eliminate the consequences of the offence or compensate damage caused by the criminal offence. There is great scope for mediation, reconciliation and reparation to play an important part in the implementation of alternative sanctions in Serbia. 
Serbia. He asked how the probation service was organized in the Netherlands, and whether it included individual work with the offender.

Koen Goei, Program Manager (NHC), said that probation officers in the Netherlands may be psychologists or pedagogues, but a vast majority of them are social workers, all of whom have regular professional trainings at work.

Eva Erren, Project Manager (CICL), introduced the participants with the project aimed at increasing the use of alternative sanctions, which is to be carried out in 2019. The basic idea underpinning the project is the Theory of Change: IF there is a capable and effective probation service and capacitated penitentiary workers, THEN the cooperation of these bodies with the judges and prosecutors will be enhanced and they will use their information and issue alternative sentences. However, if judges and prosecutors are not aware of the work done by probation workers and penitentiary workers, and how they can use this work for their benefit, then they are unlikely to seek cooperation with them. If municipalities do not know about the opportunities offered through conditional sentences and community service, they are unlikely to accept the (former) convict in the community or provide community service placement.

Finally, if the general public has a negative attitude towards community service and reintegration, then decision makers will be hesitant to let the whole system develop fast, judges and prosecutors will not increase the issuing of conditional sentences and community services, and the Ministries of Justice will not provide more funding for increased probation staff and facilities. Eva Erren also noted that there is a wider framework of trainings which will be organized, including a possibility of organizing educational training in Serbia by visiting Dutch experts (judges, prosecutors, commissioners). She also announced a new visit by the Dutch delegation, on which occasion the meeting could be held only with judges or only with prosecutors, or with both of them together. She thanked all the participants for attending the meeting and encouraged further contact and prospective cooperation.

\section{CONCLUSIONS AND RECOMMENDATIONS OF THE MEETING}

The meeting drew attention to several issues regarding the application of alternative sanctions. In general terms, the application of alternative sanctions through the engagement of the social community, civil society, victims and other social actors has changed the way in which interpersonal relations in the field of criminal sanctions work. On the other hand, the legal system has also been largely altered in this area, and now it encompasses criminal law, the execution of criminal offenses, legislation on the implementation of alternative sanctions and competent services, and many other legal relations. Thus, criminal sanctions (their determination and pronouncement), which were traditionally part of the criminal law and criminal procedure (court and prosecution), have expanded beyond these frames and they now encompass much wider segments of society.

The final discussion yielded significant conclusions which may be summarized and presented in several key recommendations for improving further application of alternative sanctions in Serbia. In some parts, these conclusions and recommendations exceed the Project framework and scope of activities because they refer to wider social segments which are closely related to different legal areas mentioned in the open discussion. In a broader sense, the outlined recommendations express the needs and directions that would 
foster a better penal policy in Serbia in accordance with the envisaged targets concerning the purpose of punishment. Such a criminal policy inevitably involves alternative sanctions. We can summarize the recommendations as follows:

1) There is a need to improve and strengthen the services responsible for pronouncing and execution of alternative sanctions (courts, prosecution offices, probation services, and prison staff), and to develop mutual cooperation and cooperation with the civil society.

- The probation service should be obliged to submit reports on the defendants' personal, family and social circumstances to the court and the prosecutor's office before the decision on the type of criminal sanction and degree of punishment is made.

- Courts and prosecutors should develop close professional cooperation and efficient collaboration with probation services

- Probation officers should provide support and assistance to detainees during their preparation for conditional release.

- Probation services should provide relevant information to judges and prosecutors on the advantages of alternative sanctions in general and in individual cases (on the perpetrator's personality, significant personal and social circumstances, etc.).

- In order to develop their "professional competence", probation officers should receive further training, and their work should be subject to supervision and assessment.

- The quality of probation services should be improved by establishing a quality assurance and control system.

- There is a need to develop an institutional framework for implementing solutions comprising the elements of restorative justice, especially in terms of confronting the victim and the perpetrator.

- Competent state authorities and institutions should establish closer cooperation with the civil society in order to ensure a wider application of alternative sanctions.

- It is vital to improve communication between all relevant actors in the application of alternative sanctions (courts, prosecution offices, probation services, prison staff).

2) There is a need to provide for a more extensive application of conditional release (parole).

- Relevant institutions should be obliged to submit to the court more complete reports on the convicted offender prior to the decision on conditional release; such reports should be submitted by the prison institution where the convicted offender is serving a sentence and by other state institutions and services (social service, psychologist, etc.).

- It is essential to establish more efficient cooperation between institutions/organizations and persons in charge of custodial treatment prior to releasing the convicted person on parole, as well as providing for their post-penal assistance and support.

- The courts should more actively propose and impose some measures in conjunction with conditional release. These measures are stipulated in Article 44 of the Act on the Execution of Non-Custodial Sanctions: ${ }^{20}$ obliging the offender to regularly report to the authority in charge of the enforcement of protective supervision; training the offender for a particular occupation; providing employment that corresponds to the offender's abilities; obliging the offender to refrain from visiting certain places, clubs

\footnotetext{
${ }^{20}$ Act on Execution of Non-Custodial Sanctions and Measures, Official Gazette RS, 55/2014, 87/2018.
} 
or events if they are likely to create an opportunity or an incentive for re-offending; timely notification of change of the place of residence, address or workplace; refraining from the use of drugs or alcohol; visiting certain professional and other counseling centers or institutions, and acting on their instructions.

3) There is a need to provide for a more intensive application of the community service.

- Judges and public prosecutors should be instructed on the advantages of pronouncing this alternative sanction, both for the perpetrator and the society.

- It is essential to increase and intensify the application and enforcement of the community service penalty.

- It is essential to create conditions and develop capacities for the application of the community service penalty (to the greatest possible extent) in different enterprises, institutions and organizations where convicts may perform the community service.

- It is essential to inform/educate the public and obtain support from the community and the environment for the application of the community service penalty.

- Convicted offenders should be informed about the benefits of the community service in order to eliminate any personal resistance against this sanction; considering that community service is often perceived as degrading or humiliating, the convicted offenders should be made aware that the community service is not aimed at undermining their dignity, honor and reputation but that it involves socially useful work acceptable to every person and that it has numerous advantages and positive effects both for the person serving the sentence and for the community.

4) There is a need to develop and organize trainings on alternative sanctions for judges, public prosecutors and probation officers.

- The education of judges and public prosecutors on the application of alternative sanctions should particularly focus on determining custodial sentences and their replacement with other milder measures, as well as on a more extensive application of the community service and conditional release (from the aspect of proposing conditional release, deciding on conditional release, the need to pronounce the prescribed measures in conjunction with conditional release, etc.).

- Judges and prosecutors should be trained to better understand the purpose of imposing alternative sanctions in accordance with the established legal framework.

- Judges and public prosecutors should be also introduced to the standards set by the Council of Europe in the field of alternative sanctions

- It is essential to consider introducing guidelines for judges and prosecutors for the purpose of achieving standardization and uniformity of criminal policy, especially with regard to alternative sanctions.

5) There is a need to inform the citizens about alternative sanctions and strengthen the public confidence in the judicial system.

- Citizens should be informed about the relevance of alternative sanctions that may be used instead of detention, particularly the importance of community service penalty and the ultimate purpose of detention.

- In order to gain public confidence and familiarize the citizens with the concepts of alternative sanctions and restorative justice, it is necessary to organize public presentations, round tables, workshops, or impart information through media. 
- The public confidence in alternative sanctions may be promoted by:

- improving relations between the public and the persons in charge of the application and execution of alternative sanctions;

- conducting public opinion polls on the topic of alternative sanctions;

- organizing conferences, seminars and other activities on a regular basis in order to raise awareness about the need for the general public participation in the implementation of alternative sanctions;

- developing a constructive public attitude towards these sanctions through media;

- promoting the reputation of probation services, courts and public prosecution offices in public.

6) There is a need to ensure relevant support to both victims and perpetrators in the application of alternative sanctions.

- The victims and perpetrators should be informed about the concepts of alternative sanctions and restorative justice.

- The victims and perpetrators should be provided assistance and support in the process of application of alternative sanctions.

- It is of vital importance to ensure the sustainability of services that provide assistance and support to victims and perpetrators in these processes.

7) Alternative sanctions should be given priority in the process of determining the type and degree of punishment for minor criminal offences, first-time offenders and vulnerable groups (women, children, persons with mental illnesses, drug addicts, elderly prisoners, persons with disabilities, foreign prisoners).

- The rights of women in criminal proceedings need to be protected. In the process of imposing criminal sanctions on female offenders, the court should take into account the degree of victimization, child care, the responsibility and the circumstances under which the crime was committed, and priority should be given to alternative sanctions.

- Prosecutors and judges should increase the application of alternative sanctions in cases involving minor offenses.

- As for juvenile offenders, detention should be imposed as the ultimate measure aimed at ensuring the minor's presence in criminal proceedings, when such a measure is truly necessary and in case another milder measure cannot achieve the same purpose; instead of detention, priority should be given to the alternative measures.

- It is essential to prescribe and conduct regular assessments (in shorter periods) on the needs of long-term prisoners, including rehabilitation, reintegration and health care, as well as to adopt mechanisms or supplement legal regulations on early release of longterm prisoners (in addition to regular legal provisions on conditional release) and to consider replacing the rest of a prison sentence with an alternative sanction.

- It is necessary to collect data on the number of persons with disabilities in prison institutions, assess their needs and inform the competent services, personnel and government authorities about it in order to ensure adequate treatment of these persons in compliance with the international standards. It is also essential to envisage a possibility for early release on a suspended sentence for these offenders, and substitute the sentence of imprisonment with an alternative measure. Related activities should 
include the training of prison staff, judges and public prosecutors, probation officers, as well as informing the wider community in order to prevent discriminatory treatment and abuse of persons with disabilities.

8) There is a need to improve the legal framework of alternative sanctions and the quality of positive law provisions.

- The legislator should continue the reform of the criminal justice system and improve the legal provisions relating to alternative sanctions already prescribed by law.

- The legislator has to provide more precise definitions of restorative justice processes (mediation, out-of-court settlement), which have already been recognized and prescribed in our legislation, in order to explicitly regulate the process of referral, the course of the restorative justice process, and its correlation with the existing criminal justice system. This may be achieved by amending the Mediation Act, which should precisely regulate the mediation procedure in criminal matters.

- There is a need to provide explicit legal norms clearly defining the position and role of the victim, in cases involving the application of alternative sanctions, measures and types of treatment.

- It is essential to harmonize the legal terminology on this matter because relevant legislative acts and by-laws contain different legal terms, which are not always and fully synonymous.

- Legal provisions on the execution of "house imprisonment" should be amended by prescribing relevant forms of treatment to be carried out in the course of serving the alternative sanction of a "house imprisonment".

- The legislator should also consider introducing legal restrictions for imposing shortterm imprisonment.

- The Criminal Procedure Code provisions on the application of the principle of opportunity (deferral of prosecution) should more precisely define the role of the victim, and particularly the victim's consent to the implementation of all the envisaged obligations. It would provide a more efficient control of decisions made by the public prosecutor in terms of the principle of opportunity.

After the discussion, the participants of the meeting attended the closing ceremony. In the closing address, the host and the organizer thanked all the attendees and particularly the respectable delegation from the Netherlands for their active participation in the meeting and significant contribution to the exchange of knowledge, experiences and best practices on the application of alternative sanctions in the Netherlands and Serbia. While looking forward to hosting another expert meeting on this subject matter, the host and the organizer expressed their enthusiasm to embark on the implementation of the project "Strengthening the Probation and the System of Alternative Sanctions in Montenegro and Serbia".

\section{REFERENCES}

Aebi, F. Marcelo, Delgrande, N., (2012). Council of Europe Annual Penal Statistics: SPACE I-2010, Survey 2010, Strasbourg, 23 March 2012, University of Lausanne, Switzerland.

Aertsen, I. (2006). The intermediate position of restorative justice: the case of Belgium, in: Aersten, I., Daems, T., Robert, L. (eds.) Institutionalizing Restorative Justice. Devon: Willan Publishing, pp.68-92.

Bergeron, J. (2017). European Parliament Committee on Civil Liberties, Justice and Home Affairs, Report on prison systems and conditions, 6 July 2017 (2015/2062(INI)), A8-0251/2017. 
Bewley-Taylor, R. D., Nougier, M. (2018). Measuring the 'World Drug Problem': 2019 and Beyond, in: Axel Klein, Blaine Stothard (eds.) Collapse of the Global Order on Drugs: From UNGASS 2016 to Review 2019, pp.65-83.

Clobusa, F. (2018). An introduction on the Dutch probation practice, Matra Rule of Law Training ProgrammeDetention and Alternative Sanctions, Veenhuizen, $7^{\text {th }}$ October 2018

Franklin, T.W., Franklin, C.A., Pratt, T.C. (2006). "Examining the empirical relationship between prison crowding and inmate misconduct: A meta-analysis of conflicting research results", Journal of Criminal Justice, 34, pp. 401-412.

Green, D., (2012). When Children Kill Children: Penal Populism and Political Culture, Oxford: Oxford University Press.

Global Prison Trends 2018, Penal Reform International, Thailand Institute of Justice, (2018).

Human Rights Watch (2018), World Report 2018, https://www.hrw.org/sites/default/files/world_report_ download/201801world_report_web.pdf

Hagemann, O. (2003). Restorative Justice in Prison? in: Walgrave, L. (ed.) Repositioning Restorative Justice. Devon: Willan Publisher: 221-236.

Johnstone, G. (2014). Restorative Justice in Prisons: Methods, Approaches and Effectiveness, European Committee on Crime Problems, Council for Penological Co-operation, Strasbourg, 29 September 2014.

Lappi-Seppälä, T., (2012). Explaining national differences in the use of imprisonment, in: S. Snacken, E. Dumortier (eds.), Resisting punitiveness in Europe? Welfare, Human Rights and Democracy, Oxon: Routledge, pp. 35-72.

Maruna, S., (2011). Why Do They Hate Us? Making Peace between Prisoners and Psychology, International Journal of Offender Therapy and Comparative Criminology, 55, 2011, pp. 671- 685.

McNeill, F., (2012). Scientific recommendation, in: Flore, D., Bosly, S., Honhon A. and Maggio J. (eds) Probation Measures and Alternative Sanctions in the European Union, Cambridge, Intersentia.

Pitts, J.M.A, Griffin, O.H.G., Johnson, W.W. (2014). Contemporary prison overcrowding: short-term fixes to a perpetual problem, Contemporary Justice Review: Issues in Criminal, Social, and Restorative Justice, 17, pp. 124-139.

Rovner, J. (2017). Juvenile Life without Parole: An Overview, The Sentencing Project, 13 October 2017.

Snacken, S., McNeill, F., (2012). Chapter 2: Scientific Recommendations, in: D. Flore, S. Bosly, A. Honhon, J. Maggio (Eds.), Probation Measures and Alternative Sanctions in the European Union, 561-571, Cambridge: Intersentia.

Tuijn, N., (2018). Views of a Dutch judge on Detention, Alternative Sanction, Probation and Resocialization, Matra Rule of Law Training Programme - Detention and Alternative Sanctions, the Hague, 10 October 2018.

Tigest, L., (2018), The Dutch Probation in European Perspective, Matra Rule of Law Training ProgrammeDetention and Alternative Sanctions, the Hague, 8 October 2018.

UN Commission on Crime Prevention and Criminal Justice, Twenty-seventh session, 14-18 May 2018, Note by the Secretariat on world crime trends and emerging issues and responses in the field of crime prevention and criminal justice, E/CN.15/2018/10, (2018).

Van Ness, D. (2007). Prisons and restorative justice, in: Johnstone, G., Van Ness, D. W. (eds.) Handbook of Restorative Justice. Devon: Willan Publisher: 312-324.

White paper on prison overcrowding, Council for Penological Co-operation (PC-CP), Document prepared by the Directorate General Human Rights and Rule of Law, Strasbourg, 24 September 2015 (2015).

Zeleskov Doric J., Batričević, A., Kuzmanović M., (2014). Probation in Europe - Serbia, in: Probation in Europe, I. Durnesku, A.van Kalmthout (eds), Confederation of European Probation (CEP), pp.1-41

\section{LEGAL DOCUMENTS}

Krivični zakonik Republike Srbije (Criminal Code of the Republic of Serbia), Službeni glasnik RS, br.85/2005, 88/2005, 107/2005, 72/2009, 111/2009, 121/2012, 104/2013, 108/2014, 94/2016.

Zakonik o krivičnom postupku Republike Srbije (Criminal Procedure Code RS), Službeni glasnik RS, br. 72/11, 101/2011, 121/2012, 32/2013, 45/2013, 55/2014

Zakon o izvrešenju vanzavodskih sankcija (Act on Execution of Non-Custodial Sanctions and Measures), Službeni glasnik RS, br. 55/2014, 87/2018.

Zakon o posredovanju u rešavanju sporova, (Act on Mediation in Dispute Resolution), Službeni glasnik RS, br. 55/2014. 
Strategija razvoja sistema izvršenja krivičnih sankcija u Republici Srbiji do 2020. godine (Strategy for Developing the System of Execution of Criminal Sanctions in the Republic of Serbia until 2020), Službeni glasnik RS, br 114/13.

Akcioni plan za sprovođenje Strategije razvoja sistema izvršenja krivičnih sankcija u Republici Srbiji do 2020. god. (Action Plan for Implementation of the Strategy of Developing the System of Execution of Criminal Sanctions in the Republic of Serbia until 2020), Službeni glasnik RS, br 85/2014.

Recommendation Rec (2000) 22 of the Committee of Ministers of the Council of Europe to member states on improving the implementation of the European Rule on community sanctions and measures, 29 Nov. 2000, Appendix 2 to $\operatorname{Rec}(2000) 22$, Guiding principles for achieving a wider and more effective use of community sanctions and measures (point 7).

\section{PRIKAZ MEĐUNARODNOG NAUČNO-STRUČNOG SASTANKA ODRŽANOG U APELACIONOM SUDU U NIŠU POVODOM PROJEKTA "JAČANJE POVERENIČKIH SLUŽBI I SISTEMA ALTERNATIVNIH SANKIJA U CRNOJ GORI I SRBIJI" (Niš, 4. decembar 2018. god.)}

Alternativne sankcije u najširem smislu su krivičnopravne mere koje se javljaju kao zamena za kaznu zatvora. One praktično predstavljaju parapenalne sankcije u tom smislu da im nedostaje ona stvarna efektivnost svojstvena klasičnoj kazni, koja se izražava kao potpuno ograničenje nekih prava ili materijalnih vrednosti. U radu je dat prikaz međunarodnog naučno-stručnog sastanka u Apelacionom sudu u Nišu povodom projekta "Strengthening the Probation and the System of Alternative Sanctions in Montenegro and Serbia" (Jačanje povereničkih službi i sistema alternativnih sankija u Crnoj Gori i Srbiji). Učesnici sastanka su bili članovi holandske delegacije, kao i domaće sudije, javni tužioci i predstavnici povereničkih službi. Tokom predstavljanja projekta i razmene mišljenja $i$ iskustva u primeni alternativnih sankcija u Holandiji $i$ Srbiji su pomenuta brojana suštinska pitanja, koja se tiču svrhe kažnjavanja, postignutih rezultata, kao i problemi koji se javljaju u svakodnevnoj praksi u primeni alternativnih sankcija.

Ključne reči: alternativne sankcije, kazna zatvora, uslovni otpust, rad u javnom interesu, sud, tužilaštvo, probacija 